\title{
THE EFFECT OF APPLYING KNOWLEDGE MANAGEMENT PRINCIPLES IN ENSURING THE QUALITY OF HIGHER EDUCATION: M'SILA UNIVERSITY AS A MODEL
}

\author{
Hadouga Hassiba, Dr., Professor \\ Faculty of Economic Sciences, Abdelhamid Mehri Constantine 2 University, Algeria \\ E-mail: hadouga.hassiba@yahoo.fr
}

\begin{abstract}
The general purpose of this study is to study the perceptions of members of higher education institutions with regard to the application of knowledge management principles to their universities and to focus on the University of Messila, in addition to studying the difference of faculty members in their perceptions, and the impact of differences in perceptions by grade, educational level and years of experience The sample consisted of 100 faculty members from four faculties of the University of M'Sila who completed a questionnaire consisting of 36 elements covering the dimensions of knowledge management and the dimensions of achieving quality in the university. This study contributes to understanding the relationship between the principles of knowledge management and the quality of higher education.
\end{abstract}

\section{KEY WORDS}

Higher education, knowledge management, knowledge management principles, quality of higher education.

Most organizations recognize knowledge as a major resource to obtain and maintain a competitive advantage, and knowledge has become an organizational asset that increases the organization's productive and adaptive capabilities, and these organizational assets increase the members 'capabilities to improve products and services and changes in organizations' systems and processes. Motivating ideas and actions that lead to improving performance and developing innovation, and knowledge helps individuals and their organizations to keep their business sound (because employees know product lines, processes and customers), all three knowledge helps in achieving its goals, when employees leave the organization, organizations will lose not only their workforce, but You will also lose their knowledge that has developed in the workplace, this knowledge asset, an intangible organizational resource in the form of insights and experiences of individuals, which is not easy to develop overnight, as many organizations seek to maintain their knowledge in a sustainable manner, thus ensuring the participation of individuals and the transfer of their knowledge. To actions to improve their work performance, the primary goal of knowledge management is to obtain knowledge that serves the needs of employees and the strategic objectives of the organization Higher education institutions can apply knowledge management to support their tasks by increasing knowledge-based activities in line with their institutional achievements, especially improving the quality of performance, as it plays an important role in the quality performance of educational institutions.

Based on the increasing importance of knowledge management and the acceleration of its applications in various international universities, and the challenges that Algerian universities face in particular to reach a competitive advantage by improving the quality of their educational services, the study problem can be formulated as follows:

- To what extent are the principles of knowledge management applied in the higher education institution in Messila, and to what extent does the application of knowledge management principles affect the quality of higher education?

To answer the previous questions, the following hypotheses were formulated:

- H1: The University of Messila applies knowledge management according to its principles, and the university applies knowledge management according to its principles;

- H2: There is a relationship between the application of knowledge management 
principles at the university and the achievement of quality assurance at the University of M'sila.

To research the subject of study, it was divided into two axes: the theoretical side of the study; the applied side of the study.

A number of management theorists have contributed to the emergence and development of knowledge management, among them Peter Drucker, Strassman Poll and Senge Peter in the United States of America. In addition, Senge focused on Organization Learning as a cultural dimension in knowledge management. Argyris Chris, Christopher Bartlett, Leonard Dorothy Leonard and others at Harvard Business School have studied facets. The different aspects of knowledge management, and the beginning of the emergence of knowledge management to Don Marchand Don in the early eighties of the last century, as the final stage of the hypotheses related to the development of information systems (Al-Kubaisi, 2005).

The researchers differed in presenting the concept of knowledge management according to their different specializations, such as their scientific and practical backgrounds, due to the expansion of the field of knowledge management. From these definitions, we mention:

- Koeni's definition: "Define it as the conscious and intelligent understanding of the organization's culture as the ability to acquire and share collective experience (AlKubaisi, 2004);

- Knowledge management can be defined as the term expressing the processes, tools and behaviors that are jointly formulated and performed by the beneficiaries of the organization to acquire, store, distribute and apply knowledge in business processes to reach the best applications with the intention of long-term competition (Najm, 2008).

The importance of knowledge management can be summarized in the following points:

- Knowledge management is a great opportunity for organizations to reduce costs and raise their internal assets to generate new revenues (Matar,2005);

- Knowledge management is an integrative systematic process for coordinating the organization's various activities in the direction of achieving its goals (Adamson, 2005);

- Knowledge management enhances the organization's ability to maintain and improve organizational performance based on experience and knowledge;

- Knowledge management allows the organization to define the required knowledge, document the available knowledge, develop it, share it, apply it and evaluate it; (Leidner, 2001).

Knowledge management is a tool for effective organizations to invest their intellectual capital, by making access to the knowledge generated by them for other people who need it an easy and possible process (Zairi, 2003).

Defining the concept of quality in the field of higher education is a major challenge in itself, as it is difficult to define a specific definition for it or to look at it from one angle. Students, which is the total efforts made by education personnel to raise and improve the unit of the educational product in line with the needs of the beneficiary and with the capabilities and characteristics of the unit. It is not derived from the size of grants and privileges, and the rates of members of a commission... but rather the concern for customer service, whether they are from inside or outside it, from the surrounding community (Sabherwal, 2010).

The concern for quality in higher education in many countries stems from several sectors, including:

- The government that is responsible for spending on education in most countries (Muhammad, 2011);

- Citizens who pay taxes to the government (Majeed, 2008);

- Those who employ graduates (Jariu, 2010). Students and their parents;

- Faculty members and those in charge of managing higher education organizations 
(Green, 1993).

In second axis we will deal with the variables of the study and their model, and then present the results of the statistical analysis reached, through the use of statistical packages for social sciences, where the hypotheses will be tested.

A descriptive approach was followed in presenting the data and an analytical approach in analyzing its results, which aims to know the role of knowledge management, using the applied method.

The data were collected by following two methods:

- The theoretical framework of the study was determined by relying on references, periodicals and studies related to the topic;

- The questionnaire, which is the main measurement tool for collecting data in this study, to cover the variables of the model, and included the principles of knowledge management at the university, and ensuring the quality of higher education through the axes of each component.

The study population consists of the five faculties of the University of Messila, the College of Economic Sciences, Management and Business Sciences, the College of Human Sciences, the College of Letters and Languages, the College of Law and Political Science, the Institute of Sciences and Techniques of Physical and Sports Activities, and the questionnaire was distributed to 100 samples from the teaching bodies working in the faculties of the university, and 100 questionnaires were retrieved that met the conditions of the questionnaire, and after identifying the study problem and drafting the paragraphs of the questionnaire, for the period January 1, 2019 to November 1, 2019, and the questionnaire contained two variables:

- The independent variable: represented in the principles of knowledge management at the university;

- The dependent variable: represented in ensuring the achievement of quality in the university.

Statistical measures were calculated as follows:

- The frequencies and percentages were calculated to know the personal and functional characteristics of the study sample;

- Pearson correlation coefficient (Pearson correlation) to calculate the internal validity of the research tool, as well as to ensure that the relationships between the different departments of the study and the internally correct variables are correct;

- The Cronbach's Alpha coefficient (Cronbach's Alpha) was applied to measure the reliability of the research tools;

- The "mean" was also measured to determine the degree of responses of the study population towards all elements, although the mean is useful for obtaining the ranking of each element among other elements;

- The use of the standard deviation "standard deviation" was to discover the deviation of the responses of the study sample on each item and each section. It was noted that the standard deviation shows the dispersion in the study sample for each item, the variables and expressions as well as the responses of the main sections. The scale is closer.

Tables 1-4 show that it is related at the level (0.01) and this gives an indication of high internal consistency coefficients, and also indicates the validity of indicators and high enough to be valid in the application of the current study, and the research tool has acceptable reliability from Steady side, Alpha Cronbach 0.9 's overall reliability is a highly reliable value.

Table 5-7 show that the percentage of $30 \%$ are at the rank of assistant professor in section $A$ of the research sample, $22 \%$ are lecturers in department $B, 20 \%$ are in the rank of professor of higher education, and $16 \%$ are at the rank of assistant professor in section $\mathrm{B}$. $12 \%$ is the rank of lecturer in department $A$. As for scientific activities, it turns out that $60 \%$ write books, $17 \%$ publish scientific research, $15 \%$ organize scientific conferences, and $8 \%$ carry out other activities such as preparatory courses for national matches. And other activities, with regard to years of experience in higher education, $45 \%$ of those with 5 years 
or less, $30 \%$ of those with years of experience ranging from 6 to 10 years, $20 \%$ of those with 11-15 years of experience, and $5 \%$ of those with years of experience 16 years and over.

Item (5), (knowledge workers determine the available information) comes in the first place and the third item comes among other elements $(2.65 \pm 0.57)$ and this indicates that there is agreement among the research sample that the advanced knowledge cycle system that everyone can easily find information Existing.

Item (4), (New information is more attractive to learn regardless of its contribution to the organization) was classified as a third item among others $(2.65 \pm 0.60)$. This indicates that there is agreement among the research sample that the new information is more attractive to learn.

Item (1), (knowledge workers know the information they need to achieve their duties and goals) has been classified in the last item in the knowledge management acquisition section before, meaning $(2.41 \pm 0.73)$. This indicates that there is agreement between the research sample of workers. In knowledge teach them the information they need to achieve their duties and goals.

Clause (2) came, (Knowledge workers use clear techniques to acquire new knowledge), and the third came among other elements $(2.68 \pm 0.59)$, and this indicates that there is agreement between the research sample used by knowledge workers, clear techniques for acquiring modern knowledge.

As for item (3), (Knowledge workers develop networks to create knowledge), it ranked last among other items $(2.48 \pm 0.69)$, and this indicates that there is agreement among the research sample that knowledge workers develop networks to create them.

Clause (4) came, (Knowledge workers spend enough time and efforts to contribute to the educational knowledge database) and the fourth came among other elements (2.56 \pm 0.66), and this indicates that there is agreement between the research sample that knowledge workers know that they have sufficient time and effort to contribute to the educational knowledge database.

Clause (6), (In our learning environment, knowledge workers are given roles and responsibilities for storing and maintaining knowledge) came last among other elements $(2.52 \pm 0.64)$, and this indicates an agreement between a sample of research that is given. Knowledge workers roles and responsibilities for storing and maintaining knowledge.

Clause (3) came, (Knowledge workers are encouraged to make use of available knowledge). It came in third place among other items $(2.58 \pm 0.67)$, and this indicates that there is agreement among the research sample that knowledge workers are encouraged to take advantage of the available knowledge.

As for item (5), (Knowledge workers apply available knowledge to create new solutions). It ranked last among other elements $(2.61 \pm 0.62)$, and this indicates that there is agreement among the research population that knowledge workers apply available knowledge to devise new solutions.

The results of Table 12 show that the average of the items ranged between 3.75 "The application of knowledge management principles makes the university administration enjoy an ambitious strategic vision translated into achievable axes and goals" where the standard deviation was 0.45 , and between the lowest arithmetic mean achieved by the paragraph. Knowledge of making the university administration undertakes the initiative and personal participation in leading the processes of continuous development and improvement and consolidating the concepts of innovation and creativity practices "by 2.51 and the highest standard deviation of 1.78 .

The results of Table 13 showed that the average of the paragraphs ranged between 3.48 "The application of knowledge management principles makes the university interested in quality and excellence awards related to academic work" where the standard deviation was 0.62, and between the lowest arithmetic mean achieved by the paragraph. The university pays attention to the international awards criteria for the distinguished employee and researcher "by 2.40 and the highest standard deviation of 1.88".

The results of Table 14 showed that the average of the items ranged between 3.65 "The application of knowledge management principles makes the university interested in the 
university proficiency test prescribed by the Ministry of Higher Education" where the standard deviation was 0.66 , and between the lowest arithmetic mean achieved by the paragraph "The application of knowledge management principles works On making the university interested in programming its graduates within the scientific excellence competitions to judge the quality of its graduates by 2.45 and the highest standard deviation of 1.72 .

Hypothesis testing. We will work in this aspect to test the hypotheses of the study, by using the appropriate statistical method, which were formulated on the basis of the study problem and its questions, as follows:

- The first hypothesis: The University of Messila applies knowledge management according to its principles, and the university applies knowledge management according to its principles.

To test this hypothesis, the mean and standard deviation were used to determine the rank of interest for each principle.

Knowledge acquisition in the higher education environment was the first process that applied the theoretical principles of knowledge management processes with an overall average of (2.57), followed by the production of knowledge in the higher education environment with a total average of (2.54), and the third was the process of spreading knowledge management in the higher education environment with a total average of (2.53), While storing knowledge in the higher education environment is the least used process that applies the theoretical principles to knowledge management processes with an overall average of (2.52), and therefore accepts the first hypothesis that the University of M'sila applies knowledge management with its principles.

- The second hypothesis: There is a relationship between the application of knowledge management principles at the university and the achievement of quality assurance at the University of M'sila.

To test this hypothesis, a simple linear regression analysis method was used to find the relationship between the application of knowledge management principles and the elements of achieving quality assurance applied in the study.

It is noticed that there is no statistically significant correlation between the application of knowledge management principles and the leadership component with a strategic vision, as the correlation coefficients reached 0.067 at the level of $(\alpha-0.05 \geq)$, and the existence of a correlation relationship between the application of knowledge management principles and quality and excellence awards, and also the existence of a correlation relationship Between the application of the principles of knowledge management and the quality of the graduates, when the correlation coefficients reached 0.240 and 0.245 , respectively, and the significance of the relationship confirms the value of the calculated $F$, which amounted to 77.00 and 88.220 , respectively, and this confirms the validity of the hypothesis regarding the existence of a correlation relationship between the application of knowledge management principles and awards for quality and excellence And also the existence of a correlation between the application of knowledge management principles and the quality of graduates, and the incorrect hypothesis regarding the application of knowledge management principles and the leadership component with a strategic vision.

\section{CONCLUSION}

The aim of this study was to explore knowledge management at the University of Messila and demonstrate the impact of knowledge management principles on achieving quality assurance at the university from the viewpoints of faculty members, although researchers often refer to this positive effect, but the empirically confirmed link is rare. Occurrence, in this study, the positive impact of knowledge management principles on achieving quality assurance and verifying its validity is examined. The results of the study showed that the four components of knowledge principles (knowledge acquisition, knowledge production, knowledge storage and knowledge dissemination) have a significant impact on achieving quality assurance in the university. This conclusion can be applied as a starting point for managers responsible for managing knowledge through their institutions, and it 
suggests appropriate investments in knowledge management initiatives to enhance the quality of higher education, and the four principles should be developed, managed, and integrated into the practice of the university's organizational operations.

In light of the results of the study, we suggest that the University of M'sila in particular and the Algerian universities in general promote the applications of the pillars of knowledge management in particular with regard to the quality of information technology and knowledge organization. This can be done through appropriate investments in knowledge management initiatives and allocating more resources in these areas, which require adopting a clear knowledge management strategy, senior management commitment, knowledge and skills must be incorporated under the knowledge management pillar in teaching personal practices, moreover, future research is encouraged to incorporate additional variables to create more conclusive results.

\section{APPENDICES}

Table 1 - Pearson Correlation Coefficient for knowledge management acquisition items in a higher education environment

\begin{tabular}{|c|c|}
\hline $\mathrm{n} / \mathrm{n}$ & Correlation coefficient \\
\hline 1 & .576 \\
\hline 2 & $.540^{\prime \prime}$ \\
\hline 3 & .962 \\
\hline 4 & $.724^{* *}$ \\
\hline 6 & $.470^{\prime \prime}$ \\
\hline 7 & .475 \\
\hline
\end{tabular}

Source: Created based on SPSS v18 software.

Table 2 - Pearson correlation coefficient for knowledge management production items in a higher education environment

\begin{tabular}{|c|c|}
\hline $\mathrm{n} / \mathrm{n}$ & Correlation coefficient \\
\hline 1 & $.816^{\prime \prime}$ \\
\hline 2 & .486 \\
\hline 3 & $.875^{\prime \prime}$ \\
\hline 4 & $.478^{\prime \prime}$ \\
\hline 6 & $.574^{\prime \prime}$ \\
\hline 7 & $.754^{\prime \prime}$ \\
\hline
\end{tabular}

Note: ** at level 0,01. Source: Created based on SPSS v18 software.

Table 3 - Pearson Correlation Coefficient for knowledge management storage items in the higher education environment

\begin{tabular}{|c|c|}
\hline $\mathrm{n} / \mathrm{n}$ & Correlation coefficient \\
\hline 1 & .675 \\
\hline 2 & .472 \\
\hline 3 & $.571^{* *}$ \\
\hline 5 & $.780^{*}$ \\
\hline 6 & $.710^{*}$ \\
\hline 7 & .498 \\
\hline
\end{tabular}

Source: Created based on SPSS v18 software.

Table 4 - Pearson Correlation Coefficient for the items spreading knowledge management in the higher education environment

\begin{tabular}{|c|c|}
\hline $\mathrm{n} / \mathrm{n}$ & Correlation coefficient \\
\hline 1 & $.450^{\prime \prime}$ \\
\hline 2 & $.685^{\prime \prime}$ \\
\hline 3 & $.578^{* *}$ \\
\hline 4 & $.675^{\prime \prime}$ \\
\hline 6 & .752 \\
\hline
\end{tabular}

Source: Created based on SPSS v18 software. 
Table 5 - Distribution of the study sample according to scientific promotions

\begin{tabular}{|c|c|c|}
\hline Category & Frequency & Percentage, \% \\
\hline Professor of higher education & 20 & 20 \\
\hline Prof. Lecturer Department Prof. & 12 & 12 \\
\hline Lecturer Department B. & 22 & 22 \\
\hline Assistant Professor Department Prof. & 30 & 30 \\
\hline Assistant Professor Department B. & 16 & 16 \\
\hline
\end{tabular}

Source: Created based on SPSS v18 software.

Table 6 - Distribution of the study sample according to the scientific activities

\begin{tabular}{|c|c|c|}
\hline Category & Frequency & Percentage, \% \\
\hline Publish research & 17 & 17 \\
\hline Writing books & 60 & 60 \\
\hline Scientific conferences & 15 & 15 \\
\hline Other activities & 8 & 8 \\
\hline
\end{tabular}

Source: Created based on SPSS v18 software.

Table 7 - Distribution of the study population according to years of experience

\begin{tabular}{|c|c|c|}
\hline Category & Frequency & Percentage, \% \\
\hline 5 years or less & 45 & 45 \\
\hline $6-10$ years & 30 & 30 \\
\hline $11-15$ years old & 20 & 20 \\
\hline 16 years and over & 5 & 5 \\
\hline
\end{tabular}

Source: Created based on SPSS v18 software.

Table 8 - Acquiring knowledge in a higher education environment (mean, standard deviation)

\begin{tabular}{|c|c|c|c|c|}
\hline$n / n$ & Value & Mean & $\begin{array}{c}\text { St. } \\
\text { deviation }\end{array}$ & $\begin{array}{l}\text { Degree of } \\
\text { approval }\end{array}$ \\
\hline 1 & $\begin{array}{l}\text { Knowledge workers teach the information they need to achieve their duties } \\
\text { and goals. }\end{array}$ & 2.40 & 0.62 & Medium \\
\hline 2 & $\begin{array}{l}\text { If knowledge workers are asked "What is the most important information } \\
\text { needed?", They'll always give the same answer }\end{array}$ & 2.47 & 0.71 & Medium \\
\hline 3 & $\begin{array}{l}\text { Knowledge workers look for existing information to avoid duplicating past } \\
\text { efforts }\end{array}$ & 2.65 & 0.65 & Medium \\
\hline 4 & $\begin{array}{l}\text { New information is more attractive to learn regardless of its contribution to } \\
\text { the organization. }\end{array}$ & 2.55 & 0.74 & Medium \\
\hline 5 & Knowledge workers determine what information is available & 2.78 & 0.76 & Medium \\
\hline 6 & $\begin{array}{l}\text { The university's application community structure reflects the cycle of } \\
\text { knowledge. }\end{array}$ & 2.45 & 0.74 & Medium \\
\hline 7 & $\begin{array}{l}\text { The university has a well-developed knowledge course system where } \\
\text { everyone can easily find the information found }\end{array}$ & 2.54 & 0.56 & Medium \\
\hline
\end{tabular}

Source: Created based on SPSS v18 software.

Table 9 - Knowledge production in a higher education environment (mean and standard deviation)

\begin{tabular}{|c|c|c|c|}
\hline Value & Mean & $\begin{array}{c}\text { St. } \\
\text { deviation }\end{array}$ & $\begin{array}{l}\text { Degree of } \\
\text { approval }\end{array}$ \\
\hline $\begin{array}{l}1 \begin{array}{l}\text { Knowledge workers adopt clear strategies for developing knowledge, for example } \\
\text { (research and development).. }\end{array} \\
\text { (relo }\end{array}$ & 2.57 & 0.56 & Medium \\
\hline 2 Knowledge workers use straightforward techniques to acquire new knowledge. & 2.82 & 0.65 & Medium \\
\hline 3 Knowledge workers develop networks to create knowledge. & 2.75 & 0.67 & Medium \\
\hline $\begin{array}{l}4 \mid \begin{array}{l}\text { Knowledge workers focus on learning and exploring new ways to create new } \\
\text { knowledge. }\end{array} \\
\end{array}$ & 2.47 & 0.62 & Medium \\
\hline 5 Knowledge workers adapt innovative processes to create knowledge. & 2.65 & 0.67 & Medium \\
\hline $6 \begin{array}{l}\text { Knowledge workers develop methods to support the creation of new knowledge } \\
\text { (for example through training programs and rotation of duties). }\end{array}$ & 2.67 & 0.70 & Medium \\
\hline $\begin{array}{l}7 \text { Knowledge workers use the right technologies to capture new ideas and } \\
\text { experiences. }\end{array}$ & 2.47 & 0.72 & Medium \\
\hline
\end{tabular}

Source: Created based on SPSS v18 software. 
Table 10 - Storage of knowledge in a higher education environment (mean, standard deviation)

\begin{tabular}{|c|c|c|c|c|}
\hline $\mathrm{N}$ & Value & Mean & St. deviation & Degree of approval \\
\hline 1 & $\begin{array}{l}\text { Knowledge workers have clear strategies for } \\
\text { storing knowledge assets. }\end{array}$ & 2.42 & 0.68 & Medium \\
\hline 2 & $\begin{array}{l}\text { Knowledge workers are sure of what kind of } \\
\text { knowledge to store }\end{array}$ & 2.65 & 0.75 & Medium \\
\hline 3 & $\begin{array}{l}\text { Knowledge workers are encouraged to capture } \\
\text { experiences and lessons learned from best } \\
\text { practices to make them accessible to others. }\end{array}$ & 2.72 & 0.47 & Medium \\
\hline 4 & $\begin{array}{l}\text { Knowledge workers spend enough time and effort } \\
\text { to contribute to the educational knowledge } \\
\text { database. }\end{array}$ & 2.85 & 0.79 & Medium \\
\hline 5 & $\begin{array}{l}\text { In our learning environment, there is a clear } \\
\text { strategy for storing knowledge for future use. }\end{array}$ & 2.45 & 0.62 & Medium \\
\hline 6 & $\begin{array}{l}\text { In our learning environment, knowledge workers } \\
\text { are given roles and responsibilities necessary to } \\
\text { store and maintain knowledge. }\end{array}$ & 2.75 & 0.78 & Medium \\
\hline 7 & $\begin{array}{l}\text { In our learning environment, knowledge workers } \\
\text { have the right systems like databases and } \\
\text { intranets, where we can easily store our } \\
\text { documented knowledge. }\end{array}$ & 2.49 & 0.69 & Medium \\
\hline
\end{tabular}

Source: Created based on SPSS v18 software.

Table 11 - Dissemination of knowledge in the higher education environment (mean and standard deviation)

\begin{tabular}{|c|c|c|c|c|}
\hline $\mathrm{N}$ & \begin{tabular}{|c|} 
Value \\
\end{tabular} & Mean & St. deviation & Degree of approval \\
\hline 1 & $\begin{array}{l}\text { Knowledge workers have systematic approaches } \\
\text { to optimizing the use of knowledge in their } \\
\text { society's processes. }\end{array}$ & 2.68 & 0.65 & Medium \\
\hline 2 & $\begin{array}{l}\text { Knowledge workers have clear strategies on how } \\
\text { to make the best use of their knowledge. }\end{array}$ & 2.67 & 0.72 & Medium \\
\hline 3 & $\begin{array}{l}\text { Knowledge workers are encouraged to make use } \\
\text { of available knowledge. }\end{array}$ & 2.71 & 0.74 & Medium \\
\hline 4 & $\begin{array}{l}\text { Knowledge workers apply available knowledge to } \\
\text { improve jobs. }\end{array}$ & 2.64 & 0.78 & Medium \\
\hline 5 & $\begin{array}{l}\text { Knowledgeable people apply the available } \\
\text { knowledge to create new solutions. }\end{array}$ & 2.68 & 0.76 & Medium \\
\hline 6 & $\begin{array}{l}\text { Knowledge workers know how to spread available } \\
\text { knowledge among students. }\end{array}$ & 2.56 & 0.71 & Medium \\
\hline
\end{tabular}

Source: Created based on SPSS 18 software.

Table 12 - Ensuring the quality of higher education through leadership with a strategic vision (frequency, percentages and standard deviation)

\begin{tabular}{|c|c|c|c|c|}
\hline $\mathrm{n} / \mathrm{n}$ & \multicolumn{1}{|c|}{ Value } & Mean & St. deviation & 0.65 \\
\hline 1 & $\begin{array}{l}\text { The application of knowledge management principles works } \\
\text { to make the university administration enjoy an ambitious } \\
\text { strategic vision translated into achievable axes and goals }\end{array}$ & 2.68 & 0.72 \\
\hline $2 \begin{array}{l}\text { The application of knowledge management principles works } \\
\text { to make the university administration use a set of } \\
\text { communication channels to communicate its vision and } \\
\text { mission to the various categories of customers }\end{array}$ & 2.67 & 2.71 & 0.74 \\
\hline 3 & $\begin{array}{l}\text { The application of knowledge management principles works } \\
\text { to make the university administration take initiative and } \\
\text { personal participation in leading the processes of } \\
\text { continuous development and improvement and consolidate } \\
\text { concepts of innovation and creativity practices }\end{array}$ & & Medium \\
\hline
\end{tabular}

Source: Created based on SPSS v18 software.

Table 13 - Quality Assurance of Higher Education through Quality and Excellence Awards (Frequencies, Percentages and Standard Deviation)

\begin{tabular}{|c|l|c|c|}
\hline $\mathrm{n} / \mathrm{n}$ & Value & $\begin{array}{c}\text { Mean } \\
\text { deviation }\end{array}$ & $\begin{array}{c}\text { Degree of } \\
\text { approval }\end{array}$ \\
\hline 1 & $\begin{array}{l}\text { The application of knowledge management principles works to make the university } \\
\text { interested in quality and excellence awards related to academic work }\end{array}$ & 3.48 & 0.62 \\
\hline 2 & $\begin{array}{l}\text { The application of knowledge management principles makes the university interested in } \\
\text { awarding the Excellence in Scientific Research Award to its employees }\end{array}$ & 3.35 & 0.60 \\
\hline 3 & $\begin{array}{l}\text { The application of knowledge management principles works to make the university pay } \\
\text { lattention to the international awards standards for the distinguished employee and }\end{array}$ & 2.40 & 1.88 \\
\hline
\end{tabular}

Source: Created based on SPSS v18 software. 
Table 14 - Quality assurance of higher education through the quality of graduates (frequency, percentages and standard deviation)

\begin{tabular}{|c|c|c|c|c|}
\hline$n / n$ & Value & Mean & $\begin{array}{c}\text { St. } \\
\text { deviation }\end{array}$ & $\begin{array}{l}\text { Degree of } \\
\text { approval }\end{array}$ \\
\hline & $\begin{array}{l}\text { The application of the principles of knowledge management works to make the } \\
\text { university interested in the university proficiency exam prescribed by the Ministry } \\
\text { of Higher Education. }\end{array}$ & 3.48 & 0.62 & Medium \\
\hline 2 & $\begin{array}{l}\text { The application of knowledge management principles works to make the } \\
\text { university see the employment of its graduates by various business organizations } \\
\text { as an honest criterion for judging the quality of its graduates. }\end{array}$ & 3.35 & 0.60 & Medium \\
\hline & $\begin{array}{l}\text { The application of knowledge management principles works to make the } \\
\text { university interested in programming its graduates within scientific excellence } \\
\text { competitions to judge the quality of its graduates. }\end{array}$ & 2.40 & 1.88 & High \\
\hline
\end{tabular}

Source: Created based on SPSS v18 software.

Table 15 - Application of knowledge management processes and theoretical principles of knowledge management

\begin{tabular}{|c|c|c|c|}
\hline $\mathrm{n} / \mathrm{n} \mid$ Knowledge management processes & Mean & St. deviation & Ranking \\
\hline 1 Acquiring knowledge in a higher education environment education & 2.57 & 0.47 & 1 \\
\hline 2 Knowledge production in a higher education environment & 2.54 & 0.45 & 2 \\
\hline 3 Storage of knowledge in a higher education environment & 2.52 & 0.40 & 4 \\
\hline 4 Spreading knowledge in a higher education environment & 2.53 & 0.43 & 3 \\
\hline
\end{tabular}

Source: Created based on SPSS v18 software.

Table 16 - Regression analysis of the relationship between knowledge management principles and achieving quality assurance in higher education

\begin{tabular}{|c|c|c|c|}
\hline \multirow{2}{*}{\begin{tabular}{|l|}
$\mathrm{n} / \mathrm{n}$ \\
The relationship between the application of knowl
\end{tabular}} & \begin{tabular}{|l|l|}
$(\mathrm{R})$ & $\left(\mathrm{R}^{2}\right)$ \\
\end{tabular} & & 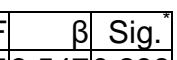 \\
\hline & 0.0670 .004 & 1.005 & 3.5470 .298 \\
\hline $\begin{array}{l}\text { The relationship between the application of knowledge management principles and } \\
\text { quality and excellence awards }\end{array}$ & 0.1500 .240 & 77.00 & 1.6900 .000 \\
\hline $\begin{array}{l}\text { The relationship between the application of knowledge management } \mathrm{p} \\
\text { the quality of graduates }\end{array}$ & & & \\
\hline
\end{tabular}

Source: Created based on SPSS v18 software.

\section{REFERENCES}

1. Ibrahim Al-Khalouf Al-Malkawi,(2007) Knowledge Management, Practices and Concepts, Al-Warraq Foundation, Amman, Edition 01,32-33.

2. Salah Al-Din Al-Kubaisi (2005).Saad Zinad Al-Mihawi, Knowledge Management, Arab Organization for Development, Cairo, 123.

3. Amer Khudair Al-Kubaisi (2004). Knowledge Management and Organization Development, Modern University Office, Alexandria, 113-114.

4. Najm Abboud Najm (2008).Knowledge Management, second edition, Al-Warraq Foundation for Publishing and Distribution, Amman, 34.

5. Abd al-Latif Mahmoud Matar (2005). Knowledge and Information Management, First Edition, House of Knowledge Treasures, Amman, 10.

6. Adamson, I (2005).Knowledge management - The next generation of TQM. Total Quality Management, 16 (8-9), 987-1000.

7. Alavi, M., \& Leidner, D. E (2001).Review: Knowledge management and knowledge management systems: conceptual foundations and research issues. MIS Quarterly, 25 (1), 107-136.

8. Alazmi, M., \& Zairi (2003). M., Knowledge management critical success factors. Total quality Management, 14 (2), 199-204.

9. Becerra-Fernandez I, Sabherwal R (2010). Knowledge Management: Systems and Processes. Armonk (NY), London: ME Sharpe, 98-99.

10. Sawsan Shaker Majeed and others (2008). Quality in Education: Applied Studies, Safaa 
Publishing and Distribution House, Amman, Edition 01, 19.

11. Shiraz Muhammad (2011).Quality Management of Educational and Research Services in Higher Education Institutions, Arab Society Library, Amman, Edition 01, 23.

12. Sawsan Shaker Majeed (2008). Muhammad Awad Al-Ziyadat, Quality and Academic Accreditation, Safaa Publishing and Distribution House, Amman, 30.

13. Inside Hasan Jariu (2010). Quality Standards and Indicators for Higher Education, The Iraqi Scientific Academy Journal, Part Two, Volume 57, 13.

14. Harvey L., Green D. (1993). Defining quality, Assessment and Evaluation in Higher Education, Vol. 18, No. 01, 38. 